\title{
Adjudicating the Utilization of Metacognitive, Affective and Social Language Learning Strategies by Preservice Learners of Teacher Education Institutions in Western Visayas, Philippines
}

\author{
Jan Dolly Grace L. Deita ${ }^{1 *} \quad$ Ofelia T. Posecion ${ }^{2}$ \\ 1.Colegio San Agustin-Bacolod, Bacolod City, Philippines \\ 2.University of Negros Occidental-Recoletos, Bacolod City, Philippines
}

\begin{abstract}
Language educators have claimed that the process of independent language learning is not just intellectual, but also social and emotional considering that language is an element of social behavior that are necessary in communicating between people. Social strategies along with affective and metacognitive strategies may help learners to achieve more effective language learning and obtain a better understanding of different cultures, understand people's feelings, attitudes, and motivation. As these indicators are considered essential in the nurturing of pre-service teachers who are college students involved in a school-based field experience, under the tutelage or supervision of cooperating teachers, and are gradually taking on more classroom management and instructional responsibilities, it is the aim of this research investigation to adjudge the utilization of metacognitive, affective and social language learning strategies of the Preservice learners of selected teacher education institutions in
\end{abstract} Western Visayas.

Specifically, this study purported to address the following questions (1). How is Language Learning Strategies utilized by Preservice learners in terms of the Metacognitive, Affective and Social dimensions? (2) Are there significant correlations in the utilization of Language Learning Strategies between and among its sub-dimensions? The researchers have hypothesized that there are no significant correlations in the utilization of Language Learning Strategies when the sub-dimensions are paired with each other; as: Metacognitive with Affective, Metacognitive with Social, and Affective with Social Language Learning Strategy.

To answer these queries, this research study had randomly chosen 349 Preservice learners from selected Teacher Education Institutions in Western Visayas as respondents of the study. The descriptive-quantitative and correlational research design was utilized by subjecting the data to Pearson Product Moment Coefficient of Correlation as the main data-analysis instrument. The data-gathering instrument which was used in this study contained the questionnaire instrument about Language Learning Strategies involving the three sub-dimensions namely Metacognitive, Affective and Social Language Learning Strategies. Furthermore, the data to determine the information required to respond to the specific problems in this research investigation were gathered by subjecting the identified respondent -Education students to a written examination.

Based on the results of this research endeavour, it is concluded that Language Learning Strategies are used by Preservice learners to a High extent, in each of the sub-dimensions namely, Metacognitive, Affective and Social Language Learning Strategies but among the three dimensions, the metacognitive strategy is the most utilized by the Preservice learners. The research results likewise showed a significant correlation between and among the utilization of Metacognitive, Affective and Social Language Learning Strategies.

Conclusively, Preservice teachers have used the three identified indirect Language Learning Strategies usually true more than half the time. Depending upon the teaching-learning environment, their use of the indirect language strategies manifest their adequate competence in syntax, mechanics, morphology and semantics, and a high retention of learning in terms of metacognitive and affective language learning strategies. The research results likewise showed a significant correlation between and among the utilization of Metacognitive, Affective and Social Language Learning Strategies.

The research results likewise showed a significant correlation between and among the utilization of Metacognitive, Affective and Social Language Learning Strategies. These results imply and maybe interpreted to mean that the utilization of Metacognitive strategies that help learners to coordinate language learning, in encouraging learners to focus on certain language activities and skills, maximize their energy and effort, as well as monitor errors and evaluate their learning progress, may be significantly influenced or affected by the utilization of their affective strategies that deal with their emotions, attitudes, motivation and values that have an impact on learners and language learning in an important way, including their anxiety management.

Nonetheless, the use of the Metacognitive and Social strategies in language learning are interchangeably affected or correlated with their use of the Social strategies that empowered language learners in asking questions, cooperating and in empathizing with others.

The researchers, being Language Teachers, recommend to introduce class activities for strategies on metacognitive, which can be used for explicit teaching, word games, readings, discussions either in online and offline venues, or oral presentations, affective strategies that can use language focus with strategies on storytelling, 
show and tell, oral presentations, discussions (online and in-class), role-playing, online skyping, peer evaluations.

For future research directions, the researchers further hope to encourage other Language Teachers to investigate on the language awareness of preservice learners, their proficiency in the use of direct and indirect strategies to develop their communicative competence, conduct similar comparative studies between the less successful learners and achievers on the utilization of the different language learning strategies to determine which is a more effective language teaching strategy to enhance students' learning.

The researchers gratefully acknowledged the cooperation and support of all the School Presidents, Vice Presidents for Academics, Deans, Faculty members and Staff of all the Teacher Education Institutions in Region VI, Western Visayas, Philippines in giving permission to allow the researchers to conduct this research investigation; the Preservice Learners of their respective Colleges/Schools of Education, for the latter's unselfish gesture of sharing their time and effort in answering the questionnaire. Due respect and recognition are likewise extended to all the authors, educators, researchers and other renowned concept writers for their expertise, wisdom and contributions in the field of language teaching and learning, and their postulates about language learning strategies, and other second language learning theories and concepts.

Keywords: Metacognitive, Affective, and Social Language Learning Strategies, Preservice learners

DOI: $10.7176 / \mathrm{JEP} / 10-35-04$

Publication date: December $31^{\text {st }} 2019$

\section{I.Introduction and Theoretical-Conceptual Background}

Many Language Educators have postulated that the process of language learning is not the processing of the intellectual, but it also about social and emotional and affective since language is an element of social behavior, and predominantly, a very essential tool for communicating with people. Social learning strategies can help learners to achieve more effective language learning and will enhance their understanding of different cultures; the affective dimension which are about peoples' feelings and attitudes, anxieties and motivation that may have an impact on the progress of language learning and performance of the preservice teachers.

These Education students who are otherwise known as Preservice teachers, upon entering senior year in tertiary education are already expected to have gained mastery in their chosen field of specialization but there are times that students tend to fall back from the things that they had learned from their lower years. As posited by educators and mentors of pre-service teachers, the purpose of pre-service experiences is to allow students to practice the strategies and concepts they have been learning in their college education courses, under the tutelage of cooperating mentors, pre-service teachers learn to prepare and give lessons and measure student progress.

With the many variations and paradigm modification in language learning, education teachers need to look for some learning strategies that would help enter the awareness and actions of the learners to achieve a learning goal.

To determine the Language Learning strategies used by the Preservice learners, the Strategies Inventory in Language Learning (SILL) introduced by Oxford was used as one of the major references of this study focusing on the Metacognitive, Affective and Social Language Learning Strategies of the Preservice learners.

Oxford (1990) described learning strategies as specific actions taken by learners to make learning "easier, faster, more enjoyable, more self-directed, more effective and more transferrable to new situations". In this manuscript, so many strategies were introduced and were divided into direct strategies and indirect strategies. Language learners use these strategies, either consciously or unconsciously, to develop their communicative competence.

Among the indirect strategies are the Metacognitive strategies which help learners to coordinate language learning, pushing learners to focus on certain language activities and skills, maximize their energy and effort, monitor errors and evaluate their learning progress, the Affective strategies which deal with emotions, attitudes, motivation and values that have an impact on learners and language learning in an important way; that lowers anxiety, and are encouraging, and Social strategies which include asking questions, cooperating and empathizing with others.

The Metacognitive Language Learning Strategy refers to the language learning strategy that goes beyond the cognitive mechanism and gives learners to coordinate their learning is anchored on the Metacognition Theory of John Flavell in his 1976 article that focused on the English learners' way of planning for learning, thinking about learning, making learning more effective, self-monitoring during learning and evaluating the success of learning in relation to their linguistic competence.

In connection to the theory of metacognition inspired by Flavell (2003), another language learning strategy is the Affective Language Learning Strategy which are used by Preservice learners which involve such affective factors like emotion, attitude, motivation, and values that influence learning importantly (Oxford,2003). Affective Language Learning Strategy is further supported by Krashen (2014) on his Krashen's Monitor Model particularly on the Affective Filter Hypothesis where it captures the relationship between affective variables and the process of second language acquisition by positing that acquirers vary concerning the strength or level of their Affective 
Filters.

To further strengthen the language learning strategies, Social Language Learning Strategy is anchored on Bandura's Social Learning Theory where it states that people learn through observing others' behavior, attitudes, and outcomes of those behaviors. This term refers to the language learning strategy to help students learn through interactions with others (Oxford, 2003). According to Bandura (2012) as cited in the article of David (2019), people learn from one another, via observation, imitation, and modeling. The theory has often been called a bridge between behaviorist and cognitive learning theories because it encompasses attention, memory, and motivation. In this research undertaking, the term Metacognitive strategies is described to refer to the activity of the language teachers to help learners to coordinate language learning, pushing learners to focus on certain language activities and skills, maximize their energy and effort, monitor errors and evaluate their learning progress.

On the other hand, those which are identified as affective strategies are expected to deal with emotions, attitudes, motivation and values that have an impact on learners and language learning importantly, including lowering anxiety, encouraging, taking emotional temperature. It is assumed that good language learners control their attitudes and emotions about learning where anxiety can be both helpful but may also be harmful, since a certain amount of anxiety can help learners to optimize their performance level, although too much anxiety has been observed to possibly hinder language learning.

In a similar context, Social strategies which are utilized by language teachers include asking questions, cooperating and empathizing with others. Citing examples on the use of these strategies, show that learning can be enhanced when people interact with each other to clarify a confusing point or when they participate in a group discussion or cooperative learning group to solve a problem. In this context, empathy means to think from another person's perspective by putting oneself in that person's situation, which can develop cultural understanding and awareness of others' thoughts and feelings.

Figure 1 showed the interplay of the three language learning strategies namely: metacognitive, affective and social language learning strategies which are utilized by the Preservice learners to enhance their language learning.

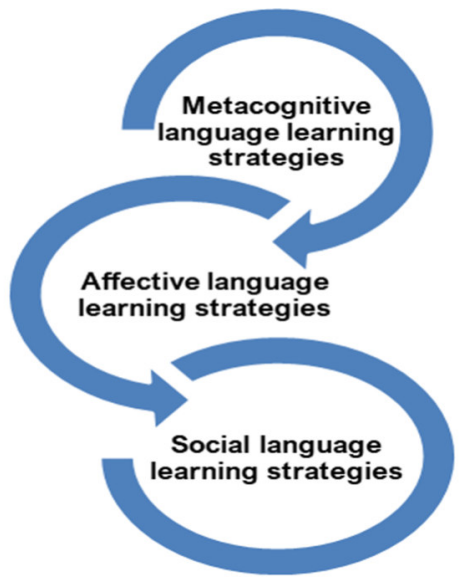

\section{The Research Problem}

This research investigation aimed to adjudge the utilization of language learning strategies in terms of metacognitive, affective and social dimensions by Preservice learners of selected teacher education institutions in Western Visayas, Philippines.

Specifically, this study purported to address the following questions:

1. How is Language Learning Strategies utilized by Preservice learners in terms of the Metacognitive, Affective and Social dimensions?

2. Are there significant correlations in the utilization of Language Learning Strategies between and among its sub-dimensions?

\section{Hypothesis}

The following hypothesis was tested in this research undertaking:

Ho1. There are no significant correlations in the utilization of Language Learning Strategies between and among its sub-dimensions.

\section{III.Related Literature}

Research into language learning strategies has increased significantly since the $1970 \mathrm{~s}$, because such categories play various important roles in language learning. Many researchers focused on how learners processed new information and what kinds of strategies they used to understand, learn or remember the information in the area of 
second or foreign language learning. Even Chamot (2005) mentioned that research on language learning strategies has a history of only about thirty years, and much of this history has been sporadic. The 1980s and early 1990s were a period of substantial research on language learning strategies, much of it descriptive. This period was followed by an apparent loss of interest in language learning strategies, judging by limited reported research and few related conference presentations. Recently, however, a number of new investigations have reinvigorated the field.

In addition, Oxford (2017) mentioned that language learning strategies are mental actions that are sometimes also manifest in observable behaviors. They are complex, dynamic, teachable, and at least partially conscious.

Furthermore, Oxford (2017) cited that language learning strategies can be orchestrated to meet immediate learning needs in specific contexts. McLaughlin (n.d.) supported Oxford's ideas about language learning strategies by mentioning in his article that Language Learning Strategies are steps taken by students to enhance their own learning. Learning strategies are especially important for language learning because they are tools for the active, self-directed involvement which is essential for communicative competence. In addition, McLaughlin (n.d) mentioned that in order to develop communicative competence, students must engage in realistic interaction using meaningful, contextualized language.

In connection with language learning strategies, a study was made by Hitt and Veliz (2015) on their attempt to uncover the Language Learning Strategies (LLSs) utilized by proficient language learners in English pedagogy programs at two universities. It was Found out that students employed indirect strategies Frequently, which are of a metacognitive in nature. Through a case study methodology, these students were asked to do a semi-structured interview and a think-aloud protocol. It was found that cognitive and metacognitive strategies were the most prevalent.

Further study had been made about language learning strategy just like in the study conducted by Fithriyah and Yusuf (2019). Their study was on the language learning strategies used by learners studying Arabic and English as foreign languages. Arabic and English are the foreign languages learnt most in Indonesia. Therefore, the researchers had investigated the students' inclinations in their learning strategies. Approximately 70 students from the Arabic and English majors at a university in Banda Aceh, Indonesia, filled in the modified Strategy Inventory for Language Learning questionnaire to obtain data. The results exposed the English students to employ more strategies than the Arabic students. From the six strategies, the Arabic students used metacognitive most, while the English students used metacognitive, compensation and social most. These strategies can be promoted in teaching so students can use them efficiently in language learning.

Another study was also made by Lu (2015) on English Learning Strategies of College

Students in Non-English Majors. The purpose of the study was aimed at investigating English learning strategies of college students in non-English majors and analyzing the differences between successful and less successful learners in terms of English learning strategies frequencies in their English learning. The result of study demonstrated that it was necessary for teachers to implement English learning strategy training in their instruction. Furthermore, it was made mentioned in the results that from the descriptive statistics, it can be seen that the means between successful and less successful learners vary much. Lu (2015) stated that the means of successful learners are much higher than that of less successful learners. It is apparent that English learning outcome is closely related with the frequency of strategy use, that is, the more strategies learners can employ in their learning, the more likely that they will be successful in their learning. Less successful learners should pay much attention to their learning approaches; they should do their utmost to cultivate the sense of implementing learning strategy in their learning. In addition, Lu (2015) added that less successful learners should alter their habitus of learning since the order of strategy frequency plays a role in learning outcome. Moreover, a study conducted by Dumam-ag (2007) about Language Learning Strategy, showed a result that the First Year Students of the University of San Jose-Recoletos students have utilized different strategies about half and more than half of the time in order to learn English Language.

In terms of Metacognitive Language Learning Strategies, awareness can be referred to as metacognition a term coined by John Flavell in the 1970's - and is of great importance in an educational context.

The concept of "metacognition" was first put forward in 1976 by John Flavell and has been developed by many researchers until today. According to Flavell as cited by Livingstone (2012), metacognition consists of both metacognitive knowledge and metacognitive experiences or regulation. Metacognition, simply put, is "thinking about thinking" or "learning how to learn. It refers to higher order thinking which involves active awareness and control over the cognitive processes engaged in learning.

To further prove that metacognitive learning strategy is important, a study conducted by Ciascai, Liliana, Haiduc, Laviniab (2013) about potential gender differences regarding the metacognitive skills of 8th graders. 91 pupils from three schools in Romania were assessed on their metacognitive skills, using the Junior Metacognitive Awareness Inventory. The findings indicate that generally both girls and boys used their metacognitive skills in learning. In addition, the results indicated that there were significant differences between boys and girls solely on the following dimensions: the perception of performance as a result of one's will and effort, the perceptions 
regarding teachers expectations about learning, the use of prior knowledge in problem-solving, planning, knowledge about one's own intellectual strengths and weaknesses, the use of various learning strategies and monitoring the learning process.

Another was the study conducted by Abhakorn (2014), on investigating the use of student portfolios to develop students' metacognition in English as a foreign language learning. The results indicated that the understanding of metacognition development through a mediated tool in language learning, and suggest EFL teachers and language educators to be aware of the importance of metacognition and reflective skills training in order to reach the full potential of the portfolio approach in language learning to be realized. In addition, Roebers, Krebs and Roderer (2014) conducted a study on metacognitive monitoring and control in elementary school children: their interrelations and their role for test performance. The results indicated that the factorial structure of monitoring, control and mastery motivation was invariant across the two age groups. There were age-dependent structural links between monitoring, control, and test performance with high confidence yielding a direct and positive effect on test performance and a direct and negative effect on adequate control behaviour in the achievement test. Mastery-oriented motivation was not found to be substantially associated with monitoring, control, or test performance underlining the importance of proximal metacognitive factors for test performance in elementary school children.

Another study made on merging metacognitive tools for use in higher education to facilitate meaningful learning was conducted by Vanhear (2016). The researcher mentioned that the current trend towards studentcentered teaching and learning is bringing about a change in emphasis in Higher Education: a shift from promoting effective teaching towards developing an understanding of how students learn. Prevalent literature calls for more emphasis on the students ${ }^{\text {ee }}$ learning process through increased metacognition and critical reflection. Therefore, the researcher's study revolved around the premise that learning takes place through the interaction of cognition (thinking), affectation (feeling) and conation (doing). Consequently, the study presented a model of teaching and learning in Higher Education through the integrated use of metacognitive tools, namely, Vee Heuristics and Concept Mapping along with an awareness of how students prefer to learn. The study of Vanhear (2016) reveled that when metacognitive tools are merged, students are empowered to embark upon a meta-learning journey which eventually leads to critical reflection and meaningful learning. Furthermore, the analysis of data revealed the powerful effect which this combination of learning tools yielded on student achievement and the research demonstrated that both students and lecturers were equally important and they should be seen as partners in achieving the intended learning outcome.

Another study to support metacognitive language learning strategy was the research conducted by Bouirane (2015). The researcher investigated the relationship between metacognitive language learning strategies (MLLS) and gender and achievement of EFL students. The researcher further cited that Metacognitive language learning strategies were crucial for students of English as a foreign language to learn effectively. The theoretical issues discussed metacognitive language learning strategies in particular, and language learning strategies (LLS) in general. The practical research took place at the English language department at Farhat Abbes University, Sétif, Algeria, with third year students learning English as a foreign language. The study hypothesized that there was a positive correlation between metacognitive language learning strategies used and achieved. Two main parts following a qualitative design constitute the body of the present research. The first part used the Metacognitive Language Learning Strategies Questionnaire (MLLSQ) to account for differences in the reported frequency of metacognitive strategies use across all the students, and across gender differences. The second part used interviews to account for the use of these strategies at the individual level, in their relation to the students 'gender and achievement in language learning. The results of the first part revealed a significant use of metacognitive strategies among all the students and significant differences between male students and female students in the frequency of use of these strategies. Moreover, the results of the second part reflected more significant differences in the use of Metacognitive strategies at the level of gender and learning achievement. With these results, the researcher concluded that by bringing together key findings and some suggestions for further research.

With all the findings revealed by the studies conducted by the researchers, it is therefore stressed out that Metacognitive Learning Strategy may somehow make a great impact to the Preservice learners.

In terms of Affective Language Learning Strategies, the article mentioned by Valdevia, McLoughlin and Mynard (91-92) on the meaning of Affect refers to the emotions, feelings, and attitudes that individuals bring to the learning experience and the role these play in motivation. The definition cited by Valdevia, McLoughlin and Mynard (91-92) was further strengthened in the study conducted by Ranjbar (2016) about relationship between teachers' affective factors (motivation, anxiety, attitude, and self-confidence) and students' motivation in EFL classrooms. Ranjbar (2016) mentioned that when students are motivated to learn, they try harder to understand the material and thereby learn more deeply, resulting in a better ability to transfer what they have learned to new situations. Moreover, Affective factors in language learning act as a barrier that filtrates the amount of input in learners' brain. Some students have very weak performance on the second language acquisition because they have little or no motivation. Ignoring the relationship between teachers' affective factors and students learning will have 
negative influence on the teaching and learning process. In addition, Samida(2012) agreed with what Valdevia, McLoughlin and Mynrad (91-92) that affective factors like emotion, attitude, motivation, and values influence learning in an important way.

Good language learners control their attitudes and emotions about learning and understand that negative feelings retard learning. Teachers can help generate positive feeling in class by giving students more responsibility, increasing the amount of natural communication, and teaching affective strategies.

Anxiety could be both helpful and harmful. It is felt that a certain amount of anxiety is helpful for learners because it helps them obtain their optimum level of performance. Too much anxiety has the opposite effect where it hinders language learning. Anxiety often takes forms of worry, frustration, insecurity, fear, and self-doubt. A common high anxiety creating situation for learners is to perform before the peers and teacher when they are not prepared. Just like in the study conducted by Galti (2016), he examined the students' awareness about the use of affective strategy as well as their level of speaking anxiety in a college of education in Nigeria. The result revealed that the students are experiencing high level of anxiety and are not using the affective strategy. In addition, the most serious form of anxiety is reported to be the fear of negative evaluation. Therefore, learners need to be motivated and set free from fear of threat to speak in class; for that learners need to be encouraged to use affective strategy like taking deep breathing, self-motivating, positive self-talk as opined by Oxford and teachers should avoid giving negative feedback to the students.

This is also true to the study conducted by Galti, Zanna and Mustapha (2016) about the Correlation between use of affective strategy and speaking anxiety among Shehu Garbai secondary school students in Maiduguri-Borno state. The result indicated that there was a strong relationship between lack of use of affective strategy and level of anxiety during speaking. In addition, the researchers mentioned that students with speaking anxiety seem not employing the affective strategy. Thus, Galti, Zanna and Mustapha (2016) believed that there was a need to make the students aware about the affective strategy and they should be encouraged to use it during speaking task in order to manage and control their speaking anxiety.

To further strengthen the importance of affective language learning strategy there was a study aimed at investigating the effect of explicit affective strategy training on Iranian EFL learners' oral language proficiency and anxiety reduction by Mostafavi and Vahdany (2016). The study aimed at investigating the possible effects of explicit teaching of affective strategies on Iranian EFL learners' oral language proficiency and the extent of their anxiety in EFL classroom. To investigate the possible effects of explicit affective strategy use instruction on the participants' oral language proficiency and their anxiety level, the pre and posttests of oral tests and the participants self-reports of anxiety control in both groups were analyzed and compared. The results of independent samples $\mathrm{T}$ - test indicated that while the two groups were homogeneous in terms of oral proficiency and level of anxiety control before introducing the treatment, the experimental group performed better than the control group in the oral post-test. Moreover, the level of anxiety control for the experimental group was significantly different and higher than that of the control group. The results confirm the positive effects of affective strategy instruction on oral language proficiency. Mostafavi and Vahdany (2016) believed that the findings of this study provide a greater understanding of affective strategy use among Iranian EFL learners. This study might also have some implications for material developers to consider strategy use in materials development.

Another study that was conducted with regard to affective language learning strategy was performed by Bekiari and Manoli (2015). The aim of their study was to investigate the relationships among perceived English as a Foreign Language (EFL) teachers' aggressive communication and students' affective learning and strategy use. There were one hundred forty-eight Greek-speaking EFL undergraduate students (39 males and 109 females), $18-23$ years old $(\mathrm{M}=20.3 \pm .68)$ participated in the study.

According to the results of the study, perceived EFL teachers' verbal aggressiveness was negatively related to their argumentativeness and students' social and affective strategy use and affective learning. Simultaneously, the results of the regression analysis revealed that perceived teachers' verbal aggressiveness and argumentativeness could significantly predict the variables of students' affective learning, social and affective strategy use. In the light of the aforementioned findings, it can be concluded that teachers' verbal aggressiveness can have a negative impact on students' feelings, which can, in turn, affect their learning process.

More studies were conducted in relation to affective language learning strategy just like in the study made on Emotions that facilitate language learning: The positive-broadening power of the imagination by McIntyre and Gregersen (2012). The researchers mentioned that the imagination was powerful, in part, because of the emotions that could be activated by imagining future states. The researchers focused on positive anticipated and anticipatory emotions related to language learning. It was argued that, in general, positive emotion had a different function from negative emotion; they were not opposite ends of the same spectrum. Furthermore, the researchers argued that positive emotion facilitates the building of resources because positive emotion tends to broaden a person's perspective, opening the individual to absorb the language. In contrast, negative emotion produces the opposite tendency, a narrowing of focus and a restriction of the range of potential language input. Therefore, this article draws a framework for finding a balance between the positive broadening and negative-narrowing emotions in the 
language classroom, and beyond. The emotion system is an engine for the positive-broadening power of the imagination.

In general, positive affect, such as enjoyment and excitement, leads learners to attend actively to the subject matter at hand, to work hard to make sense of it, and to think creatively and with an open mind about it.

In the case of Social language Learning Strategies, Oxford (2003) mentioned that Social strategies like asking questions to get verification, asking for clarification of a confusing point, asking for help in doing a language task, talking with a native-speaking conversation partner, and exploring cultural and social norms that would help the learner work with others and understand the target culture as well as the language. In addition, Varisoglu (2016) mentioned in his article that learning is a both individual and social process. For this reason, it has been expressed that there is a growth in social skills of those students who work in cooperation where in a classroom, in which a foreign language is taught, the use of cooperative learning makes dialogues among the students more efficient.

To help the preservice learners know more the importance of social language learning strategy, there was a study steered by Molleman, van den Berg and Weissing (2014) about consistent individual differences in human social learning strategies. The researchers mentioned that Social learning had allowed humans to build up extensive cultural repertoires, enabling them to adapt to a wide variety of environmental and social conditions. The researchers further mentioned that it was unclear which social learning strategies people used, especially in social contexts where their payoffs depend on the behavior of others. In their study, the researchers showed experimentally that individuals differ in their social learning strategies and that they tend to employ the same learning strategy irrespective of the interaction context. Payoff-based learners focused on their peers' success, while decision-based learners disregard payoffs and exclusively focus on their peers' past behavior. These individual differences may be of considerable importance for cultural evolution. The researchers cited that by means of a simple model they were able to demonstrate that groups harboring individuals with different learning strategies may be faster in adopting technological innovations and can be more efficient through successful role differentiation. Molleman, van den Berg and Weissing (2014) declared that their study highlighted the importance of individual variation for human interactions and sheds new light on the dynamics of cultural evolution.

Another study about Social language learning strategy was made by Hurst, Wallace and Nixon (2013) to determine our students' perceptions of the value of the social interaction that was taking place in our classrooms on their learning. Their findings revealed that students in all three courses perceived that social interaction improved their learning by enhancing their knowledge of literacy and teaching and their critical thinking and problem-solving skills.

There are more related studies on social strategies mentioned especially about the structure of communication networks according to Barkoczi and Galesic (104). The researchers said that social strategies are an important determinant of the capacity of teams, organizations and societies to solve policy, business and science problems. This is one of the reasons why social strategies are very important in learning a language because language is used in communication and communication occurs between people. This statement is further corroborated by Samida (2013) where it was mentioned that there were three sets of strategies that were included in social strategy such as asking questions, cooperating with others, and empathizing with others and among the three, asking questions is the most helpful and comes closest to understanding the meaning. It also helps in conversation by generating response from the partner and shows interest and involvement. Cooperation with others eliminates competition and, in its place, brings group spirit. Studies show that cooperative learning results in higher self-esteem, increased confidence, and rapid achievement. Learners do not naturally apply cooperative strategies because of strong emphasis put on competition by educational institutions. Sometimes competition brings a strong wish to perform better than others, but it often results in anxiety and fear of failure. It is important to help learners change their attitudes from confrontation and competition to cooperation (Samida 5).

With talks about cooperation, Antonio (2017), mentioned in his thesis that the social strategies that were introduced when he conducted his research showed that students took an active role over the communicative situations (interactive scenarios) that were proposed as part of each lesson (tasks). This aforementioned role, led students to be autonomous in regards to the use of the expressions for clarification, to cooperate with their classmates in order to solve a linguistic task and to use conversational strategies (such as showing surprise, changing the tone of voice, etc.) to convey ideas and opinions in a more natural way. Another conclusion mentioned was that the instruction of social strategies modified and configured the way in which learners interacted with their classmates and teachers. Antonio stated that interaction is about exchanging meaning in order to accomplish a specific objective which is framed within the dynamics of social interaction. That is, interaction entails paying attention to what the other says, use expressions for verification or clarification, cooperating with the other person, etc. Furthermore, learners used more negotiation strategies with their teacher and peers, they also became more aware of what was said and what was left unsaid and became more cooperative with their classmates.

Lastly, the study made by Varisoglu (2016), highlighted the importance of strategies of social language 
learning and cooperative learning in the process of teaching Turkish as a foreign language. The researcher mentioned that in teaching Turkish as a foreign language, the effective methods would be those which were arranged according to the strategies of social learning and the principles of cooperative learning. Furthermore, the researcher said that despite of a rather theoretical character of his study, the practical accuracy of his conclusion can be proven by works which evaluate the level of success of the English and German language learners. In addition, Varisoglu (2016) said that to obtain success, there was a need to support socialization attempts of every student. It is impossible to learn a foreign language at the level of the mother tongue, fully and perfectly, and to use it completely without mistakes.

However, the students can achieve the active use of language in social environment and within the process based on cooperative learning. Therefore, the researcher concluded that in the teaching of Turkish as a foreign language, it is very important that the teacher includes such activities which would bring the student to the opening of his/her language skills and which would keep him/her in a tight communication both with the teacher and the students. He further mentioned that the process of learning of Turkish by the students, their abilities to use it functionally, making acquaintance with Turkish culture and the efforts to develop communication skills were tightly connected with the abilities to establish social relations and cooperation. In order to reach absolute success in teaching and learning Turkish as a foreign language, both the teachers and the students had to make an active use of the social strategies and cooperative learning.

With all these research studies made regarding social language learning strategy the researchers were more determined to find out further the importance of the concept of social language learning strategy to the preservice learners.

Generally, it is through the bases found on the different research studies that made the researchers expound more the significance of language learning strategies particularly on metacognitive, affective and social. The results of the study would somehow let the preservice learners be aware of the language learning strategy to be used in teaching their lessons as they would be dealing with students in the future that might improve their students' learning strategies as well.

Consequently, with all these relevant research studies about the importance of the three language learning strategies, the researchers were more motivated to study the utilization of Metacognitive, Affective and Social Language Learning Strategies of Preservice Learners.

\section{V.Research Method}

To address the concerns of this research undertaking which is presently conducted, this study employed the descriptive-quantitative method of research; most specifically, the type of descriptive method that was used in this investigation is the correlational research design using the Pearson Product Moment Coefficient of Correlation. The research participants were the Preservice learners from selected colleges and universities in Western Visayas, Philippines.

Stratified random sampling was used to determine the sample size through the Slovin's formula which yielded a total of 349 Preservice learners as respondents of this study.

A test questionnaire instrument was utilized about Language Learning Strategies which was divided into three sub-dimensions namely Metacognitive, Affective and Social Language Learning Strategies.

Each of these sub-dimensions of Language Learning Strategies was made up of twenty questions, items 1-20 were all about Metacognitive Language Learning Strategy, items 21-40 were about Affective Language Learning Strategy while items 41-60 were all about Social Language Learning Strategy.

Furthermore, these items were answered using the following indicators:

\begin{tabular}{|l|l|}
\hline \multicolumn{1}{|c|}{ Responses } & \multicolumn{1}{c|}{ Interpretative Descriptions } \\
\hline Never or Almost true of me & The statement is rarely true to the respondents \\
\hline Usually not true of me & The statement is true less than half the time \\
\hline Somewhat true of me & The statement is true of about half the time \\
\hline Usually true of me & The statement is true more than half the time \\
\hline Always or Almost always true of me & The statement is true of the respondents almost always. \\
\hline
\end{tabular}

The test items were evaluated by jurors with expertise on grammar and language assessment.

The data-gathering instrument was considered reliable, if it yields consistent results (Wells \& Wollack 2), the reliability index was determined through the use of Cronbach's alpha which can be written as a function of the number of test items and the average inter-correlation among the items.

To analyze the specific problems addressed in this research work, the data collected from the questionnaire was analyzed using the Statistical Package for Social Science (SPSS).

Data analysis procedures for this phase of the study had included the calculating descriptive statistics, including means and standard deviations for the whole sample and for subgroups related to geographic area, gender, and other key variables (Newton and Rudestam 5). 
Table 1

Interpretive Scale used to describe the Metacognitive, Affective language, Social Language Learning Strategies

\begin{tabular}{|c|l|}
\hline Mean scores & \multicolumn{1}{|c|}{ Interpretation } \\
\hline $4.21-5.00$ & Very High \\
\hline $3.41-4.20$ & High \\
\hline $2.61-3.40$ & Moderate \\
\hline $1.81-2.60$ & Low \\
\hline $1.00-1.80$ & Very Low \\
\hline
\end{tabular}

To determine if there are significant correlations between the sub-dimensions of Language Learning Strategies as paired:

Metacognitive Language Learning Strategy and Affective Language Learning Strategy, Metacognitive Language Learning Strategy and Social Language Learning Strategy and Affective Language Learning Strategy and Social Language Learning Strategy the Pearson Product Moment Coefficient of Correlation was used.

\section{IV.Results of the Study}

The results of this research endeavor are presented in the tables that follow.

Research Question I. How is Language Learning Strategies utilized by Preservice learners in terms of the Metacognitive, Affective and Social dimensions?

Table 2

The utilization of Metacognitive, Affective and Social dimensions of Language Learning Strategies by

Preservice learners

\begin{tabular}{|l|c|c|c|}
\hline & N & Mean & Interpretation \\
\hline Metacognitive & 349 & 3.93 & High \\
\hline Affective & 349 & 3.74 & High \\
\hline Social & 349 & 3.69 & High \\
\hline As A Whole & 349 & 3.78 & High \\
\hline
\end{tabular}

As reflected in the table, the language learning strategies as a whole, has a mean average of 3.78. This shows that it has a High extent to which Language Learning Strategies are used by Preservice learners.

The result further supports Oxford's statement about Language Learning Strategies where learners take specific actions to make learning easier, faster, more enjoyable, more self-directed, more effective, and more transferable to new situations (9).

Furthermore, the result also corroborates Dumam-ag's research about English Language Learning Strategies where he concluded that the students have utilized different strategies about half and more than half of the time in order to learn English Language (118).

As to the Metacognitive Language Learning Strategy, the data in Table 2 shows that the Preservice learners' extent of using the Metacognitive Language Learning Strategy is High. It has a mean score of 3.93.

Since Metacognitive Language Learning Strategy according to O'Malley and Chamot (44) is a higher order executive skill that may entail planning for, monitoring or evaluating the success of a learning activity".

The result may show that Metacognitive Language Learning Strategy enables the Preservice learners to think about language independently of comprehension and production abilities.

On the other hand, the mean score of Affective Language Learning Strategy reflected a High extent of use by Preservice learners; it has a mean of 3.74. This result may imply that the affective factors like emotion, attitude, motivation, and values influence learning in an important way (Samida 4).

Furthermore, this also supports Krashen's Monitor Model particularly on the Affective Filter Hypothesis where it captures the relationship between affective variables and the process of second language acquisition by positing that acquirers vary with respect to the strength or level of their Affective Filters (32).

Moreover, Table 1 further shows the result of Social Language Learning Strategy. It has a mean of 3.69 which has a high extent of use of the Preservice learners.

This result supported the theory of Bandura about Social learning of the students in their attempt to learn English which according to Bandura's Social Learning Theory, people learn through observing others' behavior, attitudes, and outcomes of those behaviors (Bandura, Learning-Theories.com).

In summary, although the table shows that the mean scores yielded from the utilization of language learning strategy is interpreted as High, but it can be seen that among the three dimensions of language learning, the metacognitive strategy is the most utilized by the preservice learners.

Research Question 2. Are there significant correlations in the utilization of Language Learning Strategies between and among its sub-dimensions?

Table 3 reflects the data which aimed to resolve if significant correlations exist between and among the subdimensions of Language Learning Strategies: Metacognitive and Affective, Metacognitive and Social Language 
Learning Strategy and Affective and Social Language Learning Strategy.

Table 3

Table 3. Correlations between the Sub-Dimensions of Language Learning Strategies

\begin{tabular}{|c|c|c|c|c|}
\hline & Metacognitive & Affective & Social & Interpretation \\
\hline \multicolumn{5}{|c|}{ Metacognitive } \\
\hline r value & & .000 & .000 & Hypothesis is Rejected \\
\hline \multicolumn{5}{|l|}{$\mathrm{p}$-value } \\
\hline \multicolumn{5}{|l|}{ Affective } \\
\hline r value & .691 & & .000 & Hypothesis is Rejected \\
\hline \multicolumn{5}{|l|}{$\mathrm{p}$ value } \\
\hline \multicolumn{5}{|l|}{ Social } \\
\hline r value & .589 & .000 & & Hypothesis is Rejected \\
\hline $\mathrm{p}$ value & .000 & & & \\
\hline
\end{tabular}

When Metacognitive Language Learning Strategy and Affective Language Learning Strategy were paired, the result showed in Table 2 that there was a significant correlation between these two language learning strategies since the $\mathrm{r}$ value is .691 and the $\mathrm{p}$ value is .000. The hypothesis which states that there is no significant correlation between Metacognitive Language Learning Strategy and Affective Language Learning Strategy is Rejected.

This result proves that the Preservice learners' way of planning for learning, thinking about learning, making learning more effective, self-monitoring during learning and evaluating how successful learning has an influence on the way how the Preservice learners control their attitudes and emotions about learning

In like manner, the result in table 2 also shows that Metacognitive Language Learning Strategy has a significant correlation when paired with Social Language Learning Strategy since the $\mathrm{r}$ value is .589 and the $\mathrm{p}$ value is .000 .

Therefore, the hypothesis stating that there is no significant correlation of Metacognitive Language Learning Strategy and Social Language Learning Strategy is Rejected.

This may further assumed that cooperative problem solving can enhance metacognitive strategies by discussing possible approaches with team members and learning from each other and it also helps the Preservice learners in the acquisition, storage, retrieval, and use of information to make learning easier, faster, more enjoyable, more self-directed, more effective, and more transferable to new situations (Oxford9).

Equally important with the findings in Table 2 is the result of Affective Language Learning Strategy when paired with Social Language Learning Strategy. The result shows that there was a significant correlation since the $\mathrm{r}$ value is .587 and the $\mathrm{p}$ value is .000 .

The hypothesis postulating that there is no significant correlation when Affective Language Learning Strategy is paired with Social Language Learning Strategy is Rejected.

This can be inferred that Preservice Learners believed that their affective factors like emotion, attitude, motivation, and values that influence their learning (Samida 4) combined with their social relationship like cooperating with others by doing something together in the language they are learning may help them in their language learning process (Samida 5) .

\section{V.Conclusions}

This research endeavor showed that Language Learning Strategies are used by Preservice learners to a High extent, in each of the sub-dimensions namely, Metacognitive, Affective and Social Language Learning Strategies but among the three dimensions, the metacognitive strategy is the most utilized by the Preservice learners. The research results likewise showed a significant correlation between and among the utilization of Metacognitive, Affective and Social Language Learning Strategies.

Results of the research endeavor may also imply that Preservice teachers have used the three identified indirect Language Learning Strategies usually true more than half the time. Depending upon the teaching-learning environment, their use of the indirect language strategies manifests their adequate competence in syntax, mechanics, morphology and semantics, and a high retention of learning in terms of metacognitive and affective language learning strategies. On the other hand, these results, may likewise imply that not one among these strategies can be considered to fit everyone nor one that is superior to another; basically, different strategies would suit the different personalities of Preservice teachers better than it does with another, because, as claimed by other researches, the most effective learners use a good mix of strategies to maximize their learning as students as posited by Ehrman. (Ehrman, 1990; Ehrman \& Oxford, 1995); Preservice Learners who utilize affective and social language learning strategies control their feelings, motivations, and attitudes when in social situations such as in 
asking questions, communicating with others, an facilitating conversation and interaction.

The result may further suggest that the learners tend to encourage themselves to speak in the second language and their social interaction may also be a gauge in being confident to communicate with one another. These results are also somehow supported by other studies that show that the frequency of use of strategies in language learning directly relates to quicker and more effective language attainment (Nyikos \& Oxford, 1993), and regardless of assessment method; whether it may be metacognition, affective and social language learning strategies.

Consequently, the use of any of the language learning strategies becomes eventually a strategy chain; a set of strategies that interlock, complementing and mutually supportive with each other. Preservice learners' use of language learning is also worth noting that each student uses every strategy, but some strategies are used more than others; and, as cited also in some studies, there is no one strategy that is more effective than others.

\section{General Recommendations}

In view of the research findings and conclusion, the following recommendations are set forth:

The researchers, being Language Teachers, recommend to introduce class activities for strategies on metacognitive, which can be used for explicit teaching, word games, readings, discussions either in online and offline venues, or oral presentations, affective strategies that can use language focus with strategies on storytelling, show and tell, oral presentations, discussions (online and in-class), role-playing, online skyping, peer evaluations.

\section{Recommendations for Future Research Directions}

This paper likewise recommends the following initiatives for future Research Directions

1. Investigate on the language awareness of Preservice learners, their proficiency in the use of direct strategies and indirect strategies to develop their communicative competence;

2. Conduct a comparative study between the less successful learners and achievers on the utilization of the different language learning strategies to determine the correct language teaching strategy to be used in teaching. As to what language learning strategies they need to focus for the success of the students;

3. Enhance further research study that involved descriptive, experimental and correlation study studies using the other language learning strategists;

4. Supplement the use of questionnaires by means of writing tasks like journals or essays to provide wider coverage and more sample-specific data;

5. Include more factors such as age, socio- economic status, and school attended when conducting research studies on the different language learning strategies to determine the most important language learning strategy to be used by the Preservice teachers;

6. Further research study on the relationship of language learning strategy instruction to teacher characteristics like beliefs, approaches, trainings and seminars attended, attitude that might lead to an effective learning strategy instruction.

\section{Acknowledgements}

Grateful acknowledgements are due to all the School Presidents, Vice Presidents for Academics, Deans, Faculty members and Staff of all the Teacher Education Institutions in Region VI, Western Visayas, Philippines, the Preservice Learners of their respective Colleges/Schools of Education, the Preservice teachers who have been the respondents of this research undertaking, for their unselfish gesture of sharing their time and effort, in answering the questionnaire. Due respect and recognition are likewise extended to all the authors, educators, researchers and other renowned concept writers for their expertise and wisdom for their contributions in the field of language teaching and learning, and their postulates about language learning strategies, and other second language learning theories and concepts.

\section{References}

Abhakorn, M.L. Jirapa (2014). Investigating the use of student portfolios to develop students ${ }^{\text {ee }}$ metacognition in English as a foreign language learning. Journal of Language Teaching and Research, 5 (1) pp. 46-55.

Antonio, Andres(2017). Language interaction through the instruction of social learning strategies in an EFL group of tenth graders at the I.E. La Despensa, Soacha Colombia. Thesis.

Bandura, Albert. Social Learning Theory. 2012:npag. Web. 15 April 2012.<http://www.instructionaldesign.org/theories/social-learning.html>

Barkoczi, Daniel \&Galesic, Mirta (2016). Social learning strategies modify the effect of network structure on group performance. Web, 2016. https://www.ncbi.nlm.nih.gov/pmc/articles/PMC5059778/

Bekiari, Alexandra \& Manoli, Polyxeni (2016). The Influence of Teacher Aggressive Communication on Student Affective Learning and Strategy Use. Journal of Teacher Education and Educators (5)2.

Bouirane, Ahlam, Metacognitive Language Learning Strategies Use, Gender, and Learning Achievement: a Correlation Study

Web.

Retrieved: 
https://www.researchgate.net/publication/308784722_Metacognitive_Language_Learning_Strategies_Use_ Gender and Learning Achievement a Correlation Study J.anuary 2015

Ciascai, Liliana and Lavinia,Haiduc (2011). Gender differences in metacognitive skills. A study of the 8th grade pupils in Romania . International Conference on Education and Educational Psychology.

Chamot, A.U. (2005). "Language Learning Strategy Instruction: Current Issues and Research.”Annual Review of Applied Linguistics 25: 112-130.

Chamot, Anna Uhl. "Issues in Language Learning Strategy Research and Teaching."Electronic Journal of Foreign Language Teaching 1.1.2004:14-26. Web. 13 April 2012. <http://e-flt.nus.edu.sg/v1n12004/chamot.htm>

Chamot, Anna Uhl and Lisa Kupper.Learning Strategies in Foreign Instruction 22. 1989:13-24. Web. 20 April 2012.http://onlinelibrary.wiley.com/doi/10.1111/j.1944-9720.1989.tb03138.x/abstract

Chomsky, Noam(2010). Cartesian Linguistics $3^{\text {rd }}$ ed. USA: Cambridge University Press.

David L, "Social Learning Theory (Bandura)," in Learning Theories, February 7, 2019, https://www.learningtheories.com/social-learning-theory-bandura.html.

Dumam-ag, Teoddie. "English Language Learning Strategies of First Year students of the University of San JoseRecoletos. School Year 2006-2007”. Research. University of San Jose-Recoletos, 2007.

Ehrman, Madeline and Oxford, Rebecca.(1995). Adults' language learning strategies in an intensive foreign language program in the United States. Elsevier (23)3.

Flavell, John. Metacognitive Aspects of Problem Solving. The Nature of Intelligence. L.B. Resnick Ed. Hillsdale, New Jersey: Erlbaum, 1976. Web. 23 March 2012.http://www.ldrc.ca/contents/view_article/146/

Fithriya and Yusuf. The Language Learning Strategies Used by Learners Studying Arabic and English as Foreign Languages.

https://www.researchgate.net/publication/330832755 The_Language_Learning_Strategies_Used_by_Learners_Studying_Arabic_and_English_as_Foreign_Lang uages, Web. February 2019

Galti, Alhaji,Zanna, Tahiru \& Malah, Alhaji. Awareness of students' on the use of affective strategy and their level of speaking anxiety. Web. https://www.researchgate.net/publication/312234661_Awareness_of_students'on_the_use_of_affective_str ategy_and_their_level_of_speaking_anxiety.

Galti, Alhaji, Zanna, Tahiru \& Malah, Alhaji. Correlation between use of affective strategy and speaking anxiety among secondary school $\quad$ students. https://www.academia.edu/28187128/CORRELATION_BETWEEN_USE_OF_AFFECTIVE_STRATEGY AND_SPEAKING_ANXIETY_AMONG_SECONDARY_SCHOOL_STUDENTS

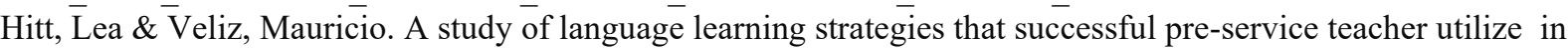
English pedagogy programs at two universities in Concepcion, Chile: a case study. file://D:/dean\%20fely\%20and\%20i/language\%20learning\%20strategies/A\%20STUDY\%20OF\%20LANG UAGE\%20LEARNING\%20STRATEGIES\%20THAT\%20SUCCESSFUL\%20PRE-SERVICE....html. Web. 2015

Hurst,Beth, Wallace, Randall \& Nixon, Sarah (2013). The Impact of Social Interaction on Student Learning. Reading horizons,(52)4.

Krashen, Stephen D. Principles and Practice in Second Language Acquisition. USA. Prentice Hall International, 1987.

Lu, Wenjun. Study on English Learning Strategies of College Students in Non-English Majors. Education Research Frontiers. December 2015, Volume 5, Issue 4, PP.81-85.

MacIntyre, Peter \& Gregersen, Tammy (2012). Emotions that facilitate language learning:The positive-broadening power of the imagination. Studies in second language learning and teaching (2)2.

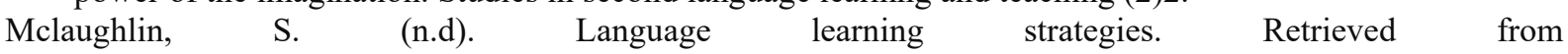
http://qattanfoundation.org/sites/default/files/u2/language_learning_strategies_13_029.pdf

Molleman, Lucas, van den Berg, Pieter,\& Weissing, Franz J. (2014). Consistent individual differences in human social learning strategies. Nature Communication.

Mostafavi, Fatemeh and Vahdany, Fereidon. (2016). The effect of explicit affective strategy training on Iranian EFL learners' oral language Proficiency and Anxiety Reduction. Advances in Language and Literary Studies, (2) 4 .

O’Malley, J. Michael and Anna Uhl Chamot.Learning Strategies in Second Language Acquisition.Cambridge: Cambridge University Press. 1990.

Oxford, Rebecca. "Language Learning Strategies in Nutshell: Update and ESL Suggestions.”TESOL Journal 2.2. 1992/1993:18-22.

---. Language Learning Strategies: What Every Teacher Should Know. New York: Newburry House, 1990.

---. Styles, Strategies and Aptitude: In connections for language learning. TS Parry and CW Stansfierl Eds. New Jersey: Prentice Hall. 1990.

Oxford, Rebecca. Classification of Language Learning Strategies. 31 July 2009:71. Web. 20 March 
2012.<http://www.plucha.info/2009/oxford\%E2\%80\%99s-classification-of-language-learning-strategies/>

---. “Language Learning Strategies: An Update Center for Applied Linguistics". Online Resources Digest. 1994:n.pag. Web, 23 March 2012.

---.Language Learning Styles and Strategies: An Overview Gala. 2003:1-24.Web. 25, March 2012.<http://web.ntpu.edu.tw/ language/workshop/read2.pdf>

Oxford, Rebecca and Nyikos, Martha. "Variable Affecting choice of Language Learning Strategies by University Students".The Modern Language Journal. 20 October 2011: 291-300.

Ranjbar ,Nahid Amini. (2016). Affective Domain: The Relationship between Teachers'

Affective Factors and EFL Students' Motivation. Journal for the Study of English Linguistics,(4)2.

Roebers, Claudia M.,Krebs, Saskia S. \& Roderer,Thomas (jnuary 2014). Metacognitive monitoring and control in elementary school children: Their interrelations and their role for test performance. Elsevier Learning and Individual Differences, 29, pp.141-149.

Rudestam, Kjell and Newton, Rae. (2014). Surviving your dissertation.USA: Sage Publication.

Samida, Deepak. Language Learning Strategies.PDF File.Web. 30 March 2012.<http://libro.dobunkyodai.ac.jp/research/pdf/treatises05/01Samidaa.pdf>

Valdivia, Sergio , David Mcloughlin and Jo Mynard. The Importance of Affective factors in Self-Access Language Learning Courses. Sisal Journal 2(2), 2011.

Vanhear, Jacqueline (2016). Merging metacognitive tools for use in higher education to facilitate meaningful learning. Doctoral thesis, Web. Retrieved: http://eprints.staffs.ac.uk/2891/.

Varisoglu. Mehmet.(2016). The importance of strategies of social language learning and cooperative learning in the process of teaching Turkish as a foreign language. Academic journals (10)11.

Wells, Craig S. and James A. Wollack . An Instructor's Guide to Understanding Test Reliability. Madison, WI: Testing \& Evaluation Services, 2003. 